\title{
Moulting Patterns in Trilobites from the Devonian of Paraná
} Basin

\author{
Padrões de Muda em Trilobitas do Devoniano da Bacia do \\ Paraná
}

\section{Patrones de mudas en Trilobites Devónicos Cuenca del Paraná}

\author{
Ariane Daniele Piccoli \\ https:/ / orcid.org/0000-0003-3032-1174 \\ ariane.piccoli@unesp.br \\ Universidade Estadual Paulista, Bauru, SP, Brazil \\ Fábio Augusto Carbonaro \\ https:/ / orcid.org/0000-0003-3614-253X \\ fabiocarbonaro@yahoo.com.br \\ Universidade Estadual Paulista, Bauru, SP, Brazil \\ Felipe Nascimento Sousa \\ https:/ / orcid.org/0000-0002-9801-0324 \\ fn.sousa@unesp.br \\ Universidade Estadual Paulista, Bauru, SP, Brazil \\ Renato Pirani Ghilardi \\ https:/ / orcid.org/0000-0003-0410-8011 \\ renato.ghilardi@unesp.br \\ Universidade Estadual Paulista, Bauru, SP, Brazil
}

\begin{abstract}
In general, trilobites had their moulting performed by the breakdown of the librigena, a region (more external) situated on the cephalon of those animals. However, phacopid (calmonid and homalonotid) trilobites from the Paraná Basin have shown a Salterian moulting pattern, differing from the other trilobites. This moult pattern consisted of the separation of all the cephalon to the thorax. So, this paper intends to demonstrate information regarding preservation standards resulting from behavior(moult) of trilobites from the Paraná Basin, as found in the literature specialized and studied scientific collections.
\end{abstract}

Keywords: Ponta Grossa Formation, Phacopida, Calmoniidae, Homalonotidae, Salterian. 
Resumo: De forma geral, os trilobitas realizavam sua muda pela quebra da librígena, uma região mais externa situada no céfalo desses animais. Contudo, os phacopídeos (calmonídeos e homalonotídeos) da Bacia do Paraná apresentam padrão Salteriano de muda, diferindo-se dos demais trilobitas. Esse padrão de muda consistia na separação de todo o céfalo em relação ao tórax. Assim, visamos demonstrar aqui informações referentes a padrões de preservação decorrentes de ação comportamental (muda) de trilobitas da Bacia do Paraná, conforme descritos na literatura especializada e em coleções científicas estudadas.

Palavras-chave: Formação Ponta Grossa, Phacopida, Calmoniidae, Homalonotidae, Salteriano.

Resumen: Por lo general, los trilobites realizaban su muda rompiendo la librígena, región mas externa ubicada en el cefalón de estos animales. Sin embargo, los facópidos (calmonid y homalonotides) de la Cuenca del Paraná tienen un patrón de muda Salteriana, a diferencia de los otros trilobites. Este patrón consistió en la separación de todo el cefalo en relación al tórax. Así, ese artículo tiene como objetivo demostrar información sobre patrones de conservación resultantes de la acción conductual (muda) de trilobites de la Cuenca del Paraná, presente en literatura especializada y colecciones científicas estudiadas.

Palabras clave: Formación Ponta Grossa, Phacopida, Calmoniidae, Homalonotidae, Salteriano.

\section{INTRODUCTION}

The Brazilian territory has four large intracratonic basins: the Amazonas Basin, located in the North; the Parnaíba Basin in the North/Northeast; the Paraná Basin in the Southeast and Solimões basin in Northwestern (Fig. 1). This paper will look specifically at Phacopid Trilobites in the Paraná Basin (Carvalho \& Ponciano, 2015).

The Paraná Basin at South America has a huge sedimentary sequence and covers an area of circa $1.500 .000 \mathrm{~km}^{2}$ along Southeastern Brazil, Eastern Paraguay, Central Uruguay, and Northeastern Argentina (Milani, 2004; Bosetti, Grahn, Horodyski \& Mendlowicz Mauller, 2012).

During the Devonian, the exposure area of Paraná Basin was marked by a division of two separate sub-basins: the Alto Garças Sub-basin (in the North) and the Apucarana Sub-basin (in the South) (Fig. 1). The formations recognized in the Apucarana Sub-basin are Furnas, Ponta Grossa, and São Domingos (Carbonaro et al., 2016).

The Devonian invertebrate fauna of the Paraná Basin strata is one of the most diversified among the Brazilian Paleozoic benthic marine faunas. It is possible to find cnidarians, brachiopods, mollusks, echinoderms, and arthropods (Simões, Leme \& Basso, 2009). Among the arthropods, trilobites were distributed in the Paleozoic seas from Lower Cambrian up to the Permo-Triassic mass extinction (Daley \& Drage, 2016; Brandt, 2002). Trilobites were a diversified group, who had several species along the geological time, occupying a variety of niches and environments (Brandt, 2002). They had many interesting 
peculiarities, one of these was the moulting, an important physiological process related to their growth.

So as well as their specific diversity, they are diverse in their moulting patterns too (Henningsmoen, 1975; McNamara and Rudkin, 1984; Speyer, 1985; Whittington, 1990; Daley \& Drage, 2016). In the case of Devonian from the Paraná Basin, it can be observed a specific moulting pattern in trilobites, the Salterian Pattern (Ghilardi, 2004; Bosetti et al., 2009). In some cases, the fossils are found in dissociated parts indicating a possible moulting from the animal, so it is necessary to distinguish the exuviae from the carcass of the fossil (Brandt, 2002).

Unfortunately, research on the subject is very scarce in Brazil, making the process more laborious. When well-studied and analyzed, it can be inferred how they lived, their morphological and behavioral characteristics, even to fill gaps in their evolutionary history (Daley \& Drage, 2016). So, in this way, this paper intends to recognize and describe the moulting patterns in the trilobites of Devonian of Paraná Basin, specifically the phacopid trilobites (calmonids and homalonotids).

Figure 1: Major Paleozoic basins of Brazil.

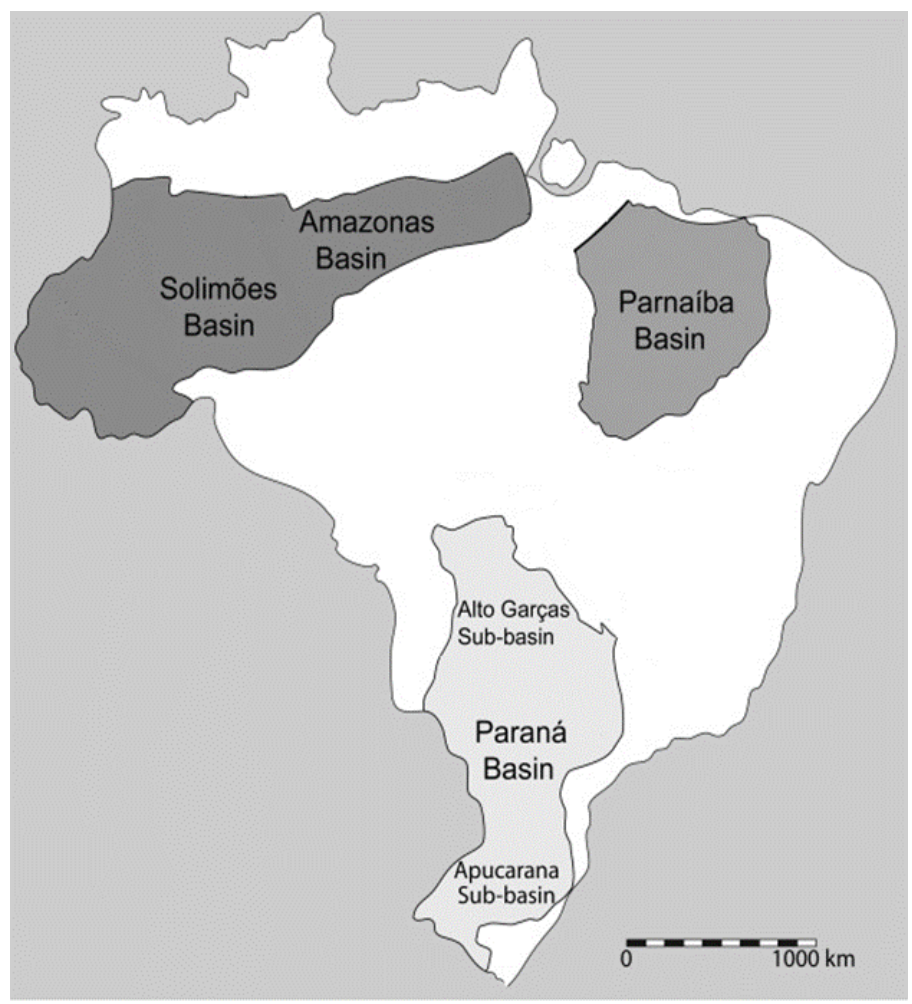

Source: modified from Grahn (1992) and Carvalho \& Ponciano (2015).

\section{THE PROCESS OF MOULTING IN TRILOBITES}

The arthropods are in a constantly growing process, so the moulting process, mediated by a steroidal hormone named ecdysone, is the reaction that those organisms 
use to adapt their exoskeleton to their new size/body. The stages between the moulting are called instars, and the period is more prolonged as the animal age (Levi-Setti, 1995; Ghilardi, 2004).

Certainly, this was a huge process in the life cycle of trilobites. According to Brandt (2002), the metabolism, behavior reproduction, and sensory acuity were affected by the replacement of the new exoskeleton, also the arthropod mortality is heightened during the process of moulting, because they were vulnerable to predators or accidents/injury in the new exoskeleton before it hardening (Henningsmoen, 1975).

The ontogenetic development of these animals can be divided into three distinct phases: in the initial phase the arthropod larvae is named Protaspis, composed only by cephalon and pygidium, measuring 0.1 to $0.3 \mathrm{~mm}$ in size. In the next phase (the intermediary), called Meraspis, the development of the thoracic segments occurs, and in the adult phase the trilobite is called Holaspis, the body size getting bigger according to the animal age (Levi-Setti, 1995).

In general, trilobites have typical molting patterns and the pattern commonly found in phacopid trilobites is the Salterian (Busch\& Swartz, 1985; Ghilardi, 2004). In the case of Salterian Pattern, the cephalon lies dissociated from the thoraco-pygidium, because the facial suture of this group is fused, at least in the most ontogenetically developed organisms (Holaspis). This fusion suggests that the exuviation may begin with the opening of the hypostomal suture, facilitating the separation of the cephalon and the thoraco-pygidium after an anterior inflection of the body (Speyer, 1985) (Fig. 2 A, B, C, and D). However, most groups of trilobites probably had adapted facial sutures and had their exuviation started by their rupture and opening. So, the soft body after exuviation was anteriorly directed, releasing itself from the exoskeleton In this way, when it comes out of the old molt, the animal forces the cephalon of this moulting to turn upside down. When present in the trilobite's body, both the vital soft cephalic parts as well as the genital and pleural spines should be preserved too.

Figure 2: A, B, C, and D - Demonstrate how the Salterian Pattern found in phacopid trilobites from Paraná Basin occurs.

A

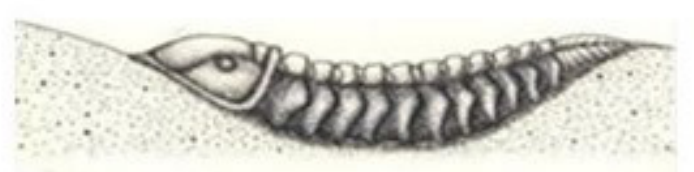

C

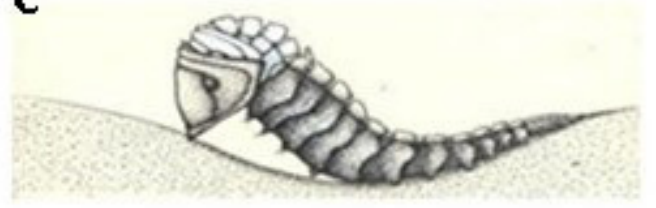

B
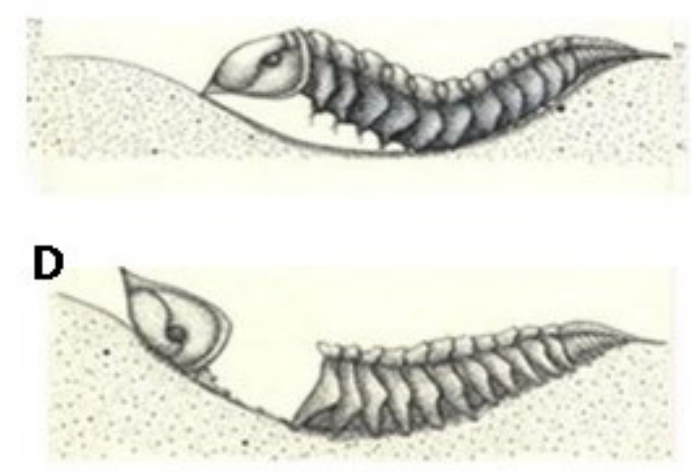

Source: adapted from Ghilardi (2004). 


\section{MATERIALS AND METHODS}

In this study, a literature review was carried with websites of institutions and associations, such as the Brazilian Geological Society and fossilworks.org.

It were analyzed trilobites fossils from the Laboratório de Paleontologia de Macroinvertebrados (LAPALMA) - UNESP, Bauru; the paleontological scientific collection from Departamento de Geologia Sedimentar of Instituto de Geociências (GP/1E) - USP, São Paulo; and the Paleontological Collection of Laboratório de Geociências (TPg) - Guarulhos University.

The fossils were in good condition, so the mechanical cleaning was not necessary, and even those with some sedimentary remnants were not cleaned due to their fragility.

\section{RESULTS}

The analyzed calmonids may have been preserved with the head flexed downwards with the anterior portion of the thorax arched, in a state of torsion. This pattern is typical of the stage of ecdysis close to the opening of the suture between the cephalon and the thorax. Others, however, are preserved with the cephalon inverted related to the thorax or cephalon close to the thorax (Fig. 3A, 3B, 3C, and 3D). This behavior is interpreted as the record of the emergence of a post-mute animal through the open suture between the cephalon and the thorax. It is important to remember that these specimens were described close to a flooding surface which suggests that this habitat is the probable place of life of this individual and, extrapolating, of this taxon. Both patterns, therefore, are representing phases of a Salterian-type exuviation and denote this habit to calmonid trilobites.

Homalonotids, in turn, are preserved, in many cases, in the form of isolated thoracopygidium and thorax-cephalon. Specimens preserved in the form of a cephalothorax are rare and probably represent entire articulated individuals who have not preserved their pigments. Additionally, in many preserved thoraco-pygids and thorax the first thoracic segment is absent, that is, the standard number for 11 segments in Burmeisteria notica holaspids are not found (GP/1E 4709, Fig. 3E) and can be inferred that is a homalonotid trilobite because the size of the animal is bigger in comparison to calmonid trilobites too. In addition, the preserved cephalon keeps the cranidium and the associated librigena. These facts characterize that the opening, during the exuviation process, took place in the hypostomal suture, characteristic, therefore, of the Salterian pattern. The rare specimens preserved in the form of a cephalothorax are attributed to post-depositional processes that did not allow the preservation, in mold, of the pigment of the complete organisms. 
Figure 3: Evidences of Salterian Pattern. A, B - examples (TPg 129 a and b, moulting of the same specimen) demonstrating the moulting of a calmonid trilobite from Ponta Grossa Formation (b)thoraco-

pygidium dissociated from the cephalon (a); C - example (GP/1E - 2592 USP) demonstrating the moulting of a calmonid trilobite from Ponta Grossa Formation. Cephalon (arrow) dissociated from the thoraco-pygidium and inverted; D - example (CCLP 1321 from LAPALMA's scientific collection) pointing cephalon dissociated from the thorax- example (GP/1E - 4709) represents the moulting of a thoracopygidium of a homalonotid trilobite from the Ponta Grossa Formation.
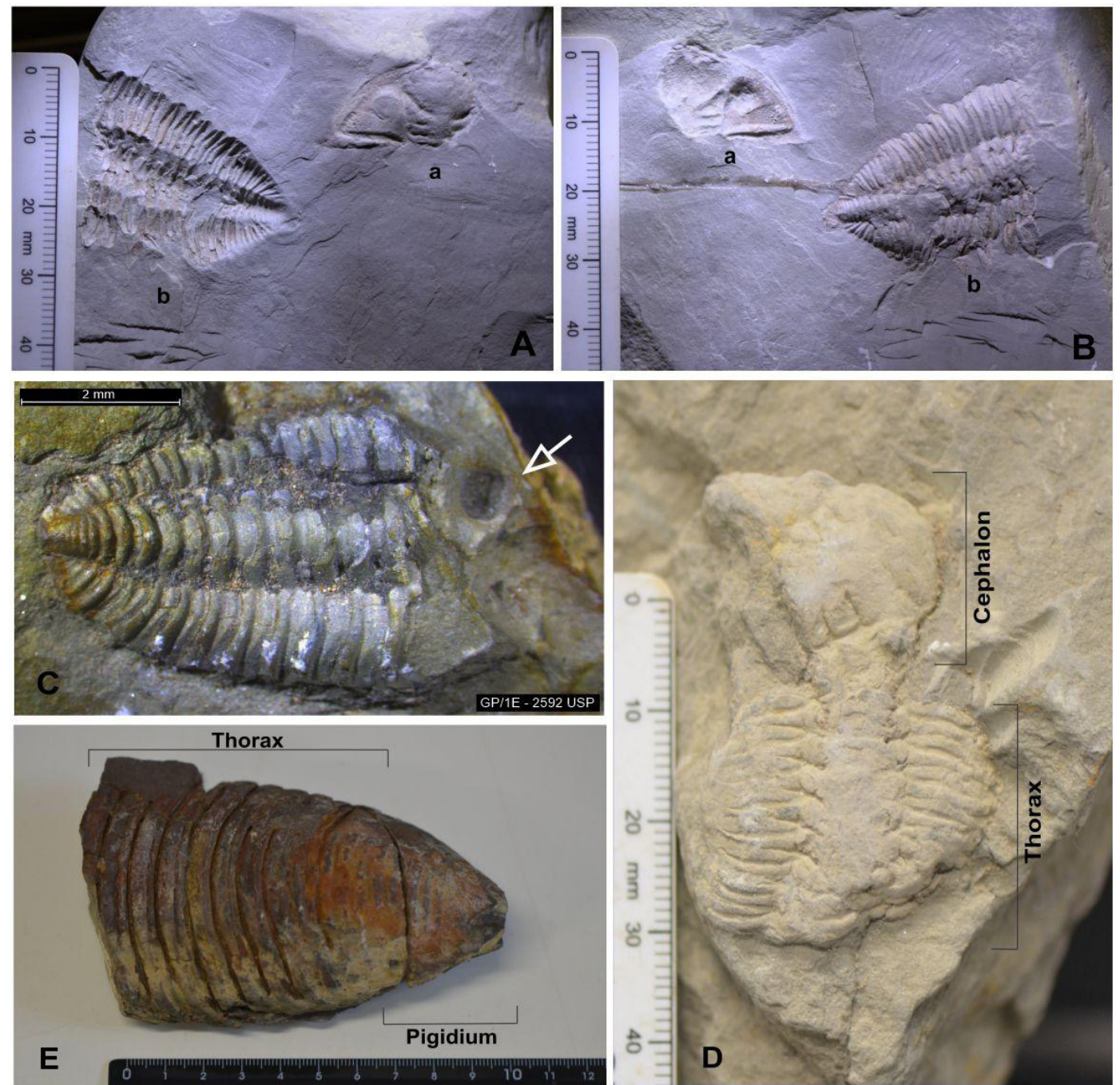

\section{DISCUSSION}

Some trilobites were benthic, epibenthic or pelagic (Brandt, 2002). Because of these habits, they could escape easily from dangerous situations, like burial. In this way, when articulated organisms (e.g. with no body parts) are found preserved, they probably represent animal carcass in life; In other words, the alive animal had greater chances to escape when it was in stressful situations. But generally trilobites are found dissociated, as a strong indication that represents exuviums. According to Henningsmoen (1975), it is much 
easier to find the exuvia than the animal carcass in the fossil record as the animal remains were quickly consumed by other animals and just the moultings were usually left intact.

In this way, due to their chitin composition and such rigidity, exuvia were not the target of predators and probably remain on substrate after the moulting process, preserved by burial conditions.

The cephalon consists of one the most important part of the trilobite's body, because they can help to identify specie(Raymond, 1921).And also, according to Henningsmoen (1975), it is accepted that the facial suture had a fundamental role during the moulting process because most trilobites probably performed the moulting by the rupture of this suture. But the phacopid trilobites demonstrate to be an exception to this rule, once their facial sutures are found fused, hardened. The fossils found in Paraná Basin showed instead probably a ventral break through a hypostomal suture (Fig. 3A, 3B, 3C, and 3D). This pattern can be seen clearly just in calmonid trilobite fossils, but as they are in the same order, we believed that the homalonotid trilobites performed this moulting process too. According to Simões, Leme \& Basso (2009) well-preserved homalonotid trilobites are rare to find in Brazilian Devonian strata, and when they are found in Ponta Grossa formation, usually represents the moulting of these organisms. Most exoskeletons found represent possible moultings dissociated and poorly preserved; only in some specific regions are found articulated or partially articulated homalonotids and, in this case, they show parts of cephalon, thorax and pygidium, as seen in the figure 3E (Simões, Leme \& Basso, 2009).

It is still opportune to mention that calmonid trilobites have mineral levels distinct from other trilobites in their exoskeleton. A higher rate of these compounds can give greater durability to calmonid carcasses, which can allow their survival for a longer time of exposure at the water/sediment interface compared to the homalonotids (Ghilardi, 2004). These information pointed out how scarce are trilobites studies and superficial especially concerning to homalonotid trilobites.

\section{ACKNOWLEDGEMENTS}

This research was supported by FAPESP (Fundação de Amparo à Pesquisa do Estado de São Paulo, process 2019/14463-9). The authors are very thankful for all support from LAPALMA (Laboratório de Paleontologia de Macroinvertebrados - UNESP/Bauru) and colleagues.

\section{REFERENCES}

Bosetti, E.P., Grahn, Y., Horodyski, R.S., \& Mendlowicz Mauller, P.(2012). The first recorded decline of the Malvinokaffric Devonian fauna in the Paraná Basin (southern Brazil) and its cause; taphonomic and fossil evidences. Journal of south American Earth sciences, 37, 228-241.doi: 10.1016/j.jsames.2012.02.006.

Bosetti, E.P., Godoy, L.C., Myszynski Jr, L.J., Horodyski, R.S., \& Zabini, C.(2009). Interpretação paleoambiental na sequência basal da formação Ponta Grossa (Devoniano) do município de Ponta Grossa, Paraná, Brasil. Terr@ Plural,3(1), 137-156.doi:10.5212/TerraPlural.v.32i1.137156 
Brandt, D.S. (2002). Ecydsial efficiency and evolutionary efficacy among marine arthropods: implications for trilobite survivorship. Alcheringa, 26(3), 399-421.

Busch, R.M., \& Swartz, F.M. (1985).Molting and description of a new homalonotid trilobite from Pennsylvania. Journal of Paleontology, 1062-1074.

Carbonaro, F.A., Meira, F. van E., Leme, J.M., Bosetti, E.P.,\& Ghilardi, R.P.(2016). Metacryphaeus tuberculatus and Metacryphaeus australis (Trilobita, Phacopida) from the Devonian of the Paraná Basin: Taxonomy and Paleobiogeography. Ameghiniana, 53(5), 552-564.

Carvalho, M.G.P.,\& Ponciano, L.C.M.O. (2015).The Devonian trilobites of Brazil: A summary. Journal of South American Earth Sciences, 64, 217-228.

Daley, A.C., \& Drage, H.B. (2016). The fossil record of ecdysis, and trends in the moulting behaviour of trilobites. Arthropod structure \& development, 45(2), 71-96.

Ghilardi, R.P. (2004). Tafonomia comparadae paleoecologia dos macroinvertebrados (ênfase em trilobites), da Formação Ponta Grossa (Devoniano, Sub-bacia Apucarana), Estado do Paraná, Brasil. Geology Thesis. Universidade de São Paulo, USP, São Paulo, SP, Brasil. Retrieved from https://teses.usp.br/teses/disponiveis/44/44136/tde08012016-144025/pt-br.php

Grahn, Y. (1992). Revision of Silurian and Devonian strata of Brazil. Palynology, 16(1), 35-61.

Henningsmoen, G. (1975). Moulting in trilobites. Fossils and Strata, 4(1), 79-200.

Levi-Setti, R. (1995). Trilobites. Chicago: University of Chicago Press.

McNamara, K.J., \& Rudkin, D.M. (1984). Techniques of trilobite exuviation. Lethaia, 17(2), 153-173.

Milani, E.J. (2004). Comentários sobre a origem e evolução tectônica da Bacia do Paraná. In Mantesso-Neto, V., BartorellI, A., Carneiro, C.D.R,\& B.B. Brito-Neves. Geologia do Continente Sul-Americano. (pp. 265-291). São Paulo: Beca.

Raymond, P.E. (1921). Criteria for species, phylogenies, and faunas of trilobites. Geological Society of America Bulletin, 32(3), 349-352. doi:10.1130/gsab-32-349.

Simões, M.G., Leme, J., \& Basso, S.P.S.(2009).Systematics, taphonomy, and paleoecology of Homalonotid Trilobites (Phacopida) from the Ponta Grossa Formation (Devonian), Paraná Basin, Brazil. Revista Brasileira de Paleontologia, 12(1), 27-42.doi:10.4072/rbp.2009.1.03

Speyer, S.E. (1985). Moulting in phacopid trilobites. Earth and Environmental Science Transactions of The Royal Society of Edinburgh, 76(2-3), 239-253.

Whittington, H.B.(1990).Articulation and exuviation in Cambrian trilobites. Philosophical Transactions of the Royal Society of London. Series B: Biological Sciences, 329(1252), 27-46.

Data de submissão: 19/abr./2021

Data de aceite: 09/set./2021 